\title{
DEVELOPMENT OF SYNBIOTIC WHEY DRINK
}

\section{POORANI. A ${ }^{1}$, SURESH SUBRAMONIAN. B ${ }^{2} \&$ ELANGO. A $^{3}$}

${ }^{1}$ Assistant Professor, Department of Livestock Products Technology, Veterinary College and Research Institute, Namakkal, Tamilnadu, India

${ }^{2}$ Professor and Head, Post Graduate Research Institute in Animal Sciences, Kattupakkam, Tamil Nadu, India

${ }^{3}$ Professor and Head, Department of Veterinary Public Health and Epidemiology,

Madras Veterinary College, Chennai, Tamil Nadu, India

\begin{abstract}
A study was undertaken to prepare synbiotic whey drink using probiotics and honey as prebiotic. The optimum acidity of 0.45 to 0.51 per cent lactic acid was reached by Bifidobacterium longum culture in 4 hr of incubation. Preliminary screening for selection of culture was done based on acidity and pH development. Acidity and pH development by Bifidobacterium longum differed significantly from all other species due to its slow acid production of 0.73 and 0.51 per cent lactic acid at $8 \mathrm{hr}$ and $4 \mathrm{hr}$ of intervals respectively. For acceptable sour taste of consumer and required level of bifidobacterial load, the performance of probiotic cultures at their log phase was considered crucial. Bifidobaterium longum was selected based on acidity and pH developed after 4 hrs of incubation viz 0.51 and 4.83 respectively. It was used for the preparation of synbiotic whey drink using paneer and cheese whey added with honey at 1.5, 2 and 2.5 per cent levels. The probiotic load of $10^{8}$ cfu/ml gives better health benefits when consumed and the maximum count of $8.93 \log _{10} c f u / m l$ was reached in $4 \mathrm{hr}$ of incubation in Synbiotic whey drink with 2 per cent honey..

KEYWORDS: Whey, Bifidobacterium Longum, Synbiotic whey Drink \& Honey
\end{abstract}

Received: Oct 06, 2017; Accepted: Oct 26, 2017; Published: Nov 14, 2017; Paper Id.: IJBTRDEC20172

\section{INTRODUCTION}

Synbiotic whey drink is a fermented milk by-product, with sweet and sour taste. To make it more dietetic whey, probiotic cultures and prebiotic substances were used, for the preparation. (1) Three different Bifidobacterial species were used as probiotics and honey was incorporated as prebiotic.

Whey contains whey proteins, which are very good source of essential amino acids, especially sulphur containing amino acids. They are also very good growth promoters of the probiotic lactic cultures. (2) Biological value, protein efficiency ratio, net protein utilization was high for whey protein, compared to casein.

\section{MATERIALS AND METHODS}

Cheese and paneer whey were obtained from whole milk. The whey was partially deproteinised at $78^{\circ} \mathrm{C}$ for $30 \mathrm{~min}$, and filtered through a muslin cloth. The whey were inoculated with Bifidobacteria species, at 2 per cent level and incubated at $37^{\circ} \mathrm{C}$ for $4-6 \mathrm{~h}$. Then, the prebiotic substance (Honey) was at 1.5 to 2.5 per cent level along with addition of different flavours and colours. (3) The final products were packed in sterile polythene bags and stored at $5^{\circ} \mathrm{C}$. 


\section{RESULTS}

\section{Composition of Cultured Paneer and Cheese Whey}

The mean chemical compositions like fat, whey protein, total solids, lactose, total ash, calcium and phosphorus content for bifidobacteria cultured paneer whey were found to be $0.50 \pm 0.038,0.79 \pm 0.012,6.07 \pm 0.178,4.32 \pm 0.097$, $0.49 \pm 0.066,0.28 \pm 0.014$ and $0.34 \pm 0.013$ percent, respectively and for cheese whey, the values were $0.58 \pm 0.014,0.67 \pm$ $0.018,6.40 \pm 0.143,4.60 \pm 0.045,0.53 \pm 0.031,0.26 \pm 0.009$ and $0.34 \pm 0.011$ percent, respectively. The values were statistically analysed for mean variance, which revealed no significant difference $(P>0.05)$.

\section{Developed Acidity in Paneer and Cheese Whey by Bifidobacterial Species}

The developed acidity at $0,2,4,6,8 \mathrm{~h}$ after inoculation of bidifus cultures in paneer and cheese whey, by three species of bifidobacteria and incubated at $37^{\circ} \mathrm{C}$ anaerobically were estimated. The developed acidity was calculated by subtracting normal acidity, from the total acidity and were furnished in Table 1 . The three species of bifidobacteria used were viz. Bifidobacterim bifidum, Bifidobacterium adolescentis, and Bifidobacterium longum. The mean values of developed acidity, as percent lactic acid in cultured paneer and cheese whey were (B. bifidum - 0.46, 0.60, 0.74, $0.94,1.02$ and $0.46,0.630 .84,1.04,1.17$ ), (B. adolescentis - 0.44, 0.53, 0.66, 0.80, 1.16 and 0.66, 0.74, 0.96, 1.10 1.26) and (B.longum - 0.33, 0.45, 0.51, 0.59, 0.73 and 0.43, 0.52, 0.59, 0.77, 0.91). Statistical anlaysis of the data revealed significance difference at $\mathrm{P} \leq 0.01$, between the species and hours. (Figure $1 \& 2$ )

\section{Influence of Bifidobacterial Species on Ph of Paneer and Cheese Whey}

The $\mathrm{pH}$ development at $0,2,4,6,8 \mathrm{~h}$ after inoculation of bifidus cultures in paneer and cheese whey, by three species of bifidobacteria incubated at $37^{\circ} \mathrm{C}$ anaerobically. The three species of bifidobacteria used were viz. Bifidobacterium bifidum, Bifidobacterium adolescentis, and Bifidobacterium longum. The mean $\mathrm{pH}$ values observed after $0,2,4,6,8 \mathrm{~h}$ in cultured paneer and cheese whey were (B. bifidum - 5.41, 4.71, 4.22, 4.11 and 5.44, 4.73, 4.33, 4.09, 4.03 (B. adolescentis - 5.49, 5.21, 4.72, 4.28, 4.02 and 4.74, 4.33, 4.21, 4.10, 3.97) and (B. longum - 5.92, 5.47, 4.83, 4.62, 4.33 and 5.40, 5.21, 4.62, 4.34, 4.27). Statistical analysis of the data revealed significance difference at $\mathrm{p} \leq 0.01$ between the species and hours.

\section{Prebiotic Effect of Honey on the Growth of Bifidobacterium Longum in Whey Drink}

The number of colonies formed by different dilutions of bifidus cultured in paneer and cheese whey, with added honey at 1.5 percent, 2 percent and 2.5 percent $\left(\mathrm{SWD}_{1.5}, \mathrm{SWD}_{2}\right.$, and $\mathrm{SWD}_{2.5}$, ) at $0,2,4,6,8 \mathrm{~h}$ of incubation were counted. The mean values of six trials were tabulated as $\log _{10}$ colony forming units per $\mathrm{ml}\left(\log _{10} \mathrm{cfu} / \mathrm{ml}\right)$. The $\log _{10} \mathrm{cfu} / \mathrm{ml}$ were paneer whey $(8.65,8.68,8.71,8.59,8.46)$ for control, $(8.81,8.81,8.83,8.81,8.75)$ for $\operatorname{SWD}_{1.5},(8.81,8.84,8.93,8.85,8.83$ for $\mathrm{SWD}_{2}$ and $(8.81,8.74,8.80,8.74,8.69)$ for $\mathrm{SWD}_{2.5}$. The $\log _{10} \mathrm{cfu} / \mathrm{ml}$ cheese whey was $(8.54,8.66,8.69,8.65,8.51)$ for control, $(8.72,8.76,8.74,8.82,8.65)$ for $\mathrm{SWD}_{1.5}$, and $(8.72,8.83,8.83,8.77,8.72)$ for $\mathrm{SWD}_{2}$ and $(8.72,8.68,8.71,8.65$, 8.54) for $\mathrm{SWD}_{2.5}$. Statistical analysis of the data revealed significant difference at $(\mathrm{p} \leq 0.01)$, between the treatments and hours.

\section{CONCLUSIONS}

The optimum acidity of 0.45 to 0.51 percent lactic acid was reached, by Bifidobacterium longum culture in $4 \mathrm{hr}$ of incubation. Preliminary screening for selection of culture, was done based on acidity and pH development. Acidity and pH 
development by Bifidobacterium longum differed significantly, from all other species, due to its slow acid production of 0.73 and 0.51 percent lactic acid at $8 \mathrm{hr}$ and $4 \mathrm{hr}$ of intervals, respectively.

For acceptable sour taste of consumer and required level of bifidobacterial load, the performance of probiotic cultures at their log phase was considered crucial. Bifidobaterium longum was selected, based on acidity and pH developed after 4 hrs of incubation viz 0.51 and 4.83, respectively. It was used for the preparation of synbiotic whey drink, using paneer and cheese whey added, with honey at 1.5, 2 and 2.5 percent levels.

The probiotic load of $10^{8} \mathrm{cfu} / \mathrm{ml}$ gives better health benefits, when consumed and the maximum count of 8.93 $\log _{10} \mathrm{cfu} / \mathrm{ml}$ was reached in $4 \mathrm{hr}$ of incubation in $\mathrm{SWD}_{2} .(5)$

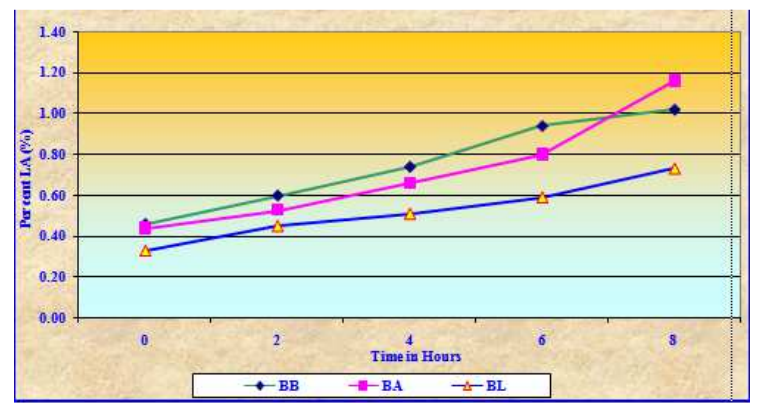

Figure 1: Effect of Three probiotic Cultures on Acid Development of Paneer Whey

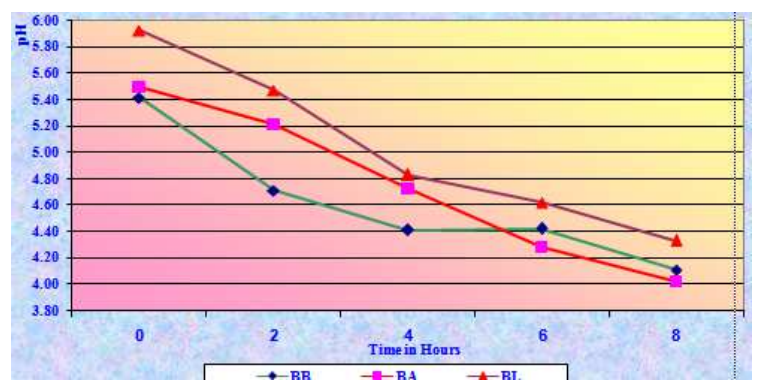

Figure 2: Effect of Three Probatic Cultures on $\mathbf{p}^{\mathrm{H}}$ Development of Paneer Whey

Table 1: Developed acidity as per cent Lactic Acid in paneer and cheese whey by bifidobacterial species $\left(37^{\circ} \mathrm{C}\right)$

\begin{tabular}{|c|c|c|c|c|c|c|c|c|c|c|}
\hline \multirow{2}{*}{$\begin{array}{c}\text { Culture } \\
\text { Organism }\end{array}$} & \multicolumn{5}{|c|}{ Hours of Incubation in Paneer Whey } & \multicolumn{5}{|c|}{ Hours of Incubation in Cheese Whey } \\
\hline & $\mathbf{0}$ & 2 & 4 & 6 & 8 & $\mathbf{0}$ & 2 & 4 & 6 & 8 \\
\hline $\begin{array}{l}\text { Bifidobacterium } \\
\text { bifidum }\end{array}$ & 0.46 & 0.60 & 0.74 & 0.94 & 1.02 & 0.46 & 0.63 & 0.84 & 1.04 & 1.17 \\
\hline $\begin{array}{l}\text { Bifidobacterium } \\
\text { adolescentis }\end{array}$ & 0.44 & 0.53 & 0.66 & 0.80 & 1.16 & 0.66 & 0.74 & 0.96 & 1.10 & 1.26 \\
\hline $\begin{array}{l}\text { Bifidobacterium } \\
\text { longum }\end{array}$ & 0.33 & 0.45 & 0.51 & 0.59 & 0.73 & 0.45 & 0.52 & 0.59 & 0.77 & 0.91 \\
\hline F- value & \multicolumn{5}{|c|}{$11.75 * *$} & \multicolumn{5}{|c|}{$30.74 * *$} \\
\hline S.E. & \multicolumn{5}{|c|}{0.0467} & \multicolumn{5}{|c|}{0.0347} \\
\hline C.D. & \multicolumn{5}{|c|}{0.1706} & \multicolumn{5}{|c|}{0.1267} \\
\hline
\end{tabular}

\# Percentages (mean) Average of six trials. Mean values bearing different superscripts are a column differs significantly $* *(\mathrm{P}<0.01)$

$\begin{array}{lll}\text { NS } & - & \text { Not Significant } \\ * & - & \text { Significant }\end{array}$


** $\quad$ - $\quad$ Highly Significant

Table 2: Influence of bifidobacterial species of $\mathrm{pH}$ of paneer and cheese whey

\begin{tabular}{|l|c|c|c|c|c|c|c|c|c|c|}
\hline \multirow{2}{*}{ Culture Organism } & \multicolumn{1}{|c|}{ Hours of Incubation in Paneer Whey } & \multicolumn{3}{c|}{ Hours of Incubation in Cheese Whey } \\
\cline { 2 - 12 } & $\mathbf{0}$ & $\mathbf{2}$ & $\mathbf{4}$ & $\mathbf{6}$ & $\mathbf{8}$ & $\mathbf{0}$ & $\mathbf{2}$ & $\mathbf{4}$ & $\mathbf{6}$ & $\mathbf{8}$ \\
\hline Bifidobacterium bifidum & 5.41 & 4.71 & 4.41 & 4.22 & 4.11 & 5.44 & 4.73 & 4.33 & 4.09 & 4.03 \\
\hline Bifidobacterium adolescentis & 5.49 & 5.21 & 4.72 & 4.28 & 4.02 & 4.74 & 4.33 & 4.21 & 4.10 & 3.97 \\
\hline Bifidobacterium longum & 5.92 & 5.47 & 4.83 & 4.62 & 4.33 & 5.40 & 5.21 & 4.63 & 4.34 & 4.27 \\
\hline F- value & \multicolumn{4}{|c|}{$91.62 * *$} & \multicolumn{5}{|c|}{$96.57 * *$} \\
\hline S.E. & \multicolumn{4}{|c|}{0.0542} & \multicolumn{5}{c|}{0.0483} \\
\hline C.D. & \multicolumn{4}{|c|}{0.1980} & \multicolumn{5}{c|}{0.1762} \\
\hline
\end{tabular}

\# Percentages (mean) Average of six trials. Mean values bearing different superscripts is a column differs significantly $* *(\mathrm{P}<0.01)$

$\begin{array}{lll}\text { NS } & - & \text { Not Significant } \\ * & - & \text { Significant } \\ * * & - & \text { Highly Significant }\end{array}$

\section{REFERENCES}

1. Brandao W \& Mendonca S,(2014)African Journal of Biotechnology Vol 13(25) 2565-2574

2. Kirsten. E. Bell \& Tim Snijders (2017) A whey protein-based multi-ingredient nutritional supplement stimulates gains in lean body mass and strength in healthy older men: controlled trial. PLoS ONE 12(7): e0181387. https://doi.org/10.1371/journal.pone.0181387

3. Sures Suresh Subramonia B, (2001). Studies on preparation of dietetic milk powder with added bifidogenic properties, (Ph.D., Thesis) submitted to Tamilnadu veterinary and Animal Sciences University, Tamilnadu, India

4. Dennis-Wall JC \& Culpepper (2017)TProbiotics (Lactobacillus gasseri KS-13, Bifidobacterium bifidum G9-1, and Bifidobacterium longum MM-2) improve rhinoconjunctivitis-specific quality of life in individuals with seasonal allergies: a double-blind, placebo-controlled, randomized trial. Am J Clin Nutr. Mar;105(3):758-767.

5. Amal BakrShori(2017)Microencapsulation Improved Probiotics Survival During Gastric Transit HAYATI Journal of Biosciences 24(1) 1-5 